\title{
Bernalar dalam Lingkaran?: Menjawab Problem Sirkularitas Doktrin Kesaksian Internal Roh Kudus
}

\section{Circular Reasoning?: Answering the Problem of Circularity in the Doctrine of Internal Witness of the Holy Spirit}

\author{
Thio Christian Sulistio \\ Sekolah Tinggi Teologi SAAT, Malang \\ christian.sulistio@seabs.ac.id
}

\begin{abstract}
Abstrak: Doktrin kesaksian internal Roh Kudus adalah doktrin yang digunakan oleh John Calvin untuk menjelaskan mengapa orang Kristen dapat memercayai Alkitab sebagai firman Allah. Namun doktrin ini tidak luput dari problem khususnya berkaitan dengan problem penalaran sirkular, subyektivisme, dan dianggap mengabaikan peran argumen dan bukti. Makalah ini berupaya menjawab problem-problem tersebut dengan pertama-tama memaparkan natur dan mekanisme kesaksian internal Roh Kudus. Kedua, menjawab problem-problem tersebut dengan menggunakan konsep pengetahuan bertingkat dan mengakui keberadaan sirkularitas epistemik. Dengan bantuan konsepkonsep tersebut penulis menunjukkan bahwa problem-problem tersebut dapat dijawab dengan baik.

Kata-kata kunci: Kesaksian, Roh Kudus, Sirkularitas, Sirkularitas Epistemik, Subyektivisme.

Abstract: The doctrine of the internal testimony of the Holy Spirit was used by John Calvin to explain why Christians can believe in the Bible as the word of God. However, this doctrine is not free from problems especially related to the problem of circular reasoning, subjectivism, and is considered to ignore evidence and arguments. This paper tries to answer these problems by first discussing the nature and mechanism of the internal testimony of the Holy Spirit. Secondly, it attempts to answer these problems by using the concept of multilevel knowledge and acknowledging the existence of epistemic circularity. With the help of these concepts, the author will show that these problems can be answered well.
\end{abstract}

Keywords: Testimony, Holy Spirit, Circularity, Epistemic Circularity, Subjectivism. 


\section{PENDAHULUAN}

Kesaksian internal Roh Kudus merupakan salah satu karya Roh Kudus di awal perjalanan hidup seorang Kristen. Kesaksian internal Roh Kudus adalah karya Roh Kudus yang meyakinkan seorang percaya (orang Kristen) bahwa Alkitab adalah firman Allah yang memiliki otoritas di dalam kehidupannya dan meyakinkannya bahwa ia adalah anak Allah. ${ }^{1}$ Meski kesaksian internal Roh Kudus berkaitan dengan masalah soteriologi dan doktrin Alkitab namun dalam sejarah teologi Kristen, kesaksian internal Roh Kudus lebih terkait dengan pemahaman bagaimana kita dapat mengenali Alkitab sebagai firman Allah. Doktrin ini dikembangkan lebih mendalam di dalam konteks perdebatan gereja Reformed, khususnya John Calvin, dengan Roma Katolik dan kalangan Anabaptis tentang sumber keyakinan kita terhadap Alkitab sebagai firman Tuhan. ${ }^{2}$

Namun karya Roh Kudus yang menyakinkan orang percaya akan otoritas Alkitab menda-

${ }^{1}$ I. John Hesselink di dalam penyelidikannya tentang karya Roh Kudus di dalam teologi Calvin menyimpulkan bahwa bagi John Calvin, kesaksian internal Roh Kudus berkaitan erat dengan keyakinan keselamatan seseorang (soteriologi) dan keyakinan dia akan otoritas Alkitab (epistemologi). I. John Hesselink, Calvin's First Catechism: A Commentary (Louisville: Westminster John Knox, 1997), 183; lih. juga Thio Christian Sulistio, "Kesaksian Internal Roh Kudus Menurut John Calvin," Veritas: Jurnal Teologi dan Pelayanan 3, no. 2 (2002): 248, https://doi.org/10.36421/veritas.v3i2.97.

${ }^{2}$ Bernard Ramm, The Witness of the Spirit: An Essay on the Contemporary Relevance of the Internal Witness of the Holy Spirit (Eugene: Wipf and Stock, 2011), 11-12; F.H. Klooster, "Internal Testimony of the Holy Spirit," dalam Evangelical Dictionary of Theology, ed. W.A. Elwell, edisi kedua (Grand Rapids: Baker, 2001), 610-611; Sulistio, "Kesaksian Internal," 244-246. Di dalam paper ini penulis tidak akan membahas doktrin kesaksian internal Roh Kudus menurut John Calvin tetapi doktrin kesaksian internal Roh Kudus itu sendiri sebagaimana yang telah dipahami oleh teolog-teolog Protestan $R e$ formed pada saat ini. Pembahasan tentang doktrin kesaksian internal Roh Kudus menurut John Calvin telah penulis bahas di Sulistio, "Kesaksian Internal," 243-253. pat tantangan dari David Friedrich Strauss, seorang teolog liberal dari Jerman (18081874). Ia pernah mengatakan bahwa doktrin tentang kesaksian internal Roh Kudus merupakan titik lemah dari teologi Protestanisme ("the Achilles' heel of the Protestan system"). ${ }^{3}$ Doktrin ini disebut sebagai titik lemah karena mengarah kepada subyektivisme di mana Roh Kudus memberitahukan kepada seseorang bahwa Alkitab adalah firman Tuhan. Dengan demikian maka otoritas tertinggi tidak terletak di dalam Alkitab yang bersifat obyektif tetapi kepada pengalaman dengan kesaksian internal Roh Kudus. Kesaksian internal Roh Kudus ini menjadi dasar atau alasan dari seseorang menerima otoritas Alkitab. ${ }^{4}$ Selain itu, doktrin ini juga mengundang penalaran yang bersifat sirkular: kita mempercayai Alkitab sebagai firman Tuhan karena karya Roh Kudus di dalam diri kita. Namun bagaimana kita mengenal karya Roh Kudus di dalam diri kita? Melalui Alkitab sebagai firman Tuhan. Penalaran seperti ini jelas bersifat sirkular dan, bagi Strauss, merupakan kelemahan di dalam teologi Protestan. ${ }^{5}$

${ }^{3}$ Dikutip dari Karl Barth, Church Dogmatic I/2, The Doctrine of the Word of God, terj. G. T. Thomson dan Harold Knight (Edinburg: T \& T Clark, 1970), 537; I. John Hesselink, "The Revelation of God in Creation and Scripture: Calvin's Theology and Its Early Reception," dalam Calvin's Theology and Its reception, ed. J. Todd Billings dan I. John Hesselink (Louisville: Westminster John Knox, 2012), 12.

${ }^{4}$ Lihat penjelasan Michael J. Kruger, Canon Revisited: Establishing the Origins and Authority of the New Testament Book (Wheaton: Crossway, 2012), 102 catatan kaki 43; G.C. Berkouwer, Holy Scripture, Studies In Dogmatics, terj. Jack B. Rogers (Grand Rapids, Eerdmans, 1975), 40; Caspar Wistar Hodge, "The Witness of the Holy Spirit to the Bible" The Princeton Theological Review 11 (1913): 52-53, https://ia801903.us.archive. org/14/items/princetontheolog1111arms/princetontheo log1111arms.pdf, diakses 26 Juni 2020.

${ }^{5}$ Pada abad 21 ini, tuduhan-tuduhan ini tidak berhenti. Tuduhan yang serupa juga diajukan oleh seorang ateis yaitu Gregory W. Dawes. Lihat Gregory W. Dawes, Religion Philosophy and Knowledge (London: Palgrave Macmillan, 2016), 138; G.W. Dawes, "Religious Studies, Faith, and Presumption of Naturalism," Jurnal Of Religion and Society 5 (2005): 10-11. 
Namun benarkah penalaran ini bersifat sirkular? Sirkularitas apa yang terdapat di dalam doktrin kesaksian internal Roh Kudus ini? Makalah ini berupaya untuk menjawab problem sirkularitas ini. Di dalam upaya untuk menjawab problem sirkularitas ini, makalah ini pertama-tama akan membahas natur dan mekanisme di dalam kesaksian internal Roh Kudus yang melibatkan unsurunsur: sifat Alkitab yang membuktikan dirinya sendiri (self-authenticating; autopistos), pengaruh noetika dosa, kemudian dilanjutkan dengan pemaparan tentang cara Roh Kudus meyakinkan orang percaya akan otoritas Alkitab. Kemudian, kedua, berdasarkan penguraian doktrin tersebut penulis akan menjawab problem sirkularitas yang mendatangi doktrin ini.

\section{AKITAB YANG BERSIFAT MEMBUKTIKAN DIRI SENDIRI (AUTOPISTOS)}

Doktrin kesaksian internal Roh Kudus terkait erat dengan doktrin Alkitab yang bersifat membuktikan dirinya sendiri. Henk van den Belt mendefinisikan Alkitab yang membuktikan dirinya sendiri sebagai: "its selfconvincing character as the written Word of God, which implies that believers find rest in it, not because of any external authority, but because of Scripture itself, through the witness of the Holy Spirit." Jika Alkitab dikatakan membuktikan dirinya sendiri itu berarti bahwa Alkitab dipercayai sebagai firman Tuhan karena Alkitab itu sendiri (karena isi Alkitab itu sendiri maupun kualitas-kualitas yang terdapat dalam Alkitab itu sendiri) dan tanpa memerlukan bukti atau argumen dari

\footnotetext{
${ }^{6}$ Henk van den Belt, The Authority of Scripture in Reformed Theology: Truth and Trust (Leiden: Brill, 2008), 303. Di dalam definisi ini, Belt mengaitkan dengan erat antara Alkitab yang bersifat membuktikan dirinya sendiri dengan karya Roh Kudus yang memampukan orang Kristen mengetahuinya. Buku Henk van den Belt ini adalah buku yang sangat baik di dalam menelusuri sejarah konsep autopistos di dalam tradisi Reformed mulai dari John Calvin hingga kini.
}

luar Alkitab. ${ }^{7}$ Bagi John Calvin Alkitab itu membuktikan dirinya sendiri sebagai firman Allah sama seperti warna putih dan rasa manis membuktikan dirinya sendiri kepada daya kognitif kita (segala perangkat di dalam diri kita yang menghasilkan kepercayaan atau beliefs) warna dan rasanya. Ia mengatakan: "Scripture exhibits fully as clear evidence of its own truth as white and black things do of their color, or sweet and bitter things do of their taste." 8

Namun apa pengertian sebenarnya tentang Alkitab yang membuktikan dirinya sendiri ini? Kruger menyatakan bahwa paling sedikit ada tiga pengertian tentang Alkitab yang membuktikan diri sendiri. ${ }^{9}$ Pertama, Alkitab yang membuktikan dirinya sebagai firman Tuhan merujuk kepada fakta bahwa Alkitab mengklaim bahwa ia adalah firman Tuhan. ${ }^{10}$ Di dalam Perjanjian Lama (PL) kita menemukan bahwa Allah berbicara langsung kepada manusia (contohnya: Kel. 20:1-4), ada

${ }^{7}$ Lihat Alvin Plantinga, Warranted Christian Belief (Oxford: Oxford University Press, 2000), 262.

${ }^{8} \mathrm{John}$ Calvin, Institutes of the Christian Religion, terj. Ford Lewis Battles (Philadelphia: Westminster Press, 1960), 1.7.2, Sulistio, "Kesaksian Internal Roh Kudus," 248.

${ }^{9}$ Kruger, Canon Revisited, 90-91.

${ }^{10}$ Lihat Te-Li Lau, "Knowing the Bible is the Word of God Despite Competing Claims," dalam The Enduring Authority of the Christian Scriptures, ed. D. A. Carson (Grand Rapids: Eerdmans, 2016), 990-991; John Murray, "The Attestation of Scripture," dalam The Infallible Word, ed. Ned B. Stonehouse dan Paul Woolley (Philadelphia: Presbyterian Guardian, 1946), 9-42; Wayne Grudem, "Scripture's Self-Attestation and the Problem of Formulating a Doctrine of Scripture," dalam Scripture and Truth, ed. D. A. Carson dan John D. Woodbridge (Grand Rapids: Zondervan, 1983), 19-59; B. B. Warfield, The Inspiration and Authority of the Bible, ed. Samuel G. Craig (Philadelphia: P \& R, 1948), 299-348. Namun Kruger berpendapat bahwa pengertian pertama ini lebih tepat disebut sebagai kesaksian Alkitab terhadap dirinya sendiri atau klaim Alkitab terhadap dirinya sendiri (self-attestation) dan bukan sifat Alkitab yang membuktikan dirinya sendiri (selfauthenticating), lih. Kruger, Canon Revisited, 90. Penulis berpendapat bahkan dalam doktrin kesaksian Alkitab terhadap dirinya sendiri tidak harus jatuh ke dalam kesalahan penalaran sirkular. 
khotbah para nabi yang dimulai dengan formula: "demikianlah firman Tuhan," yang menunjukkan bahwa berita mereka adalah dari Allah, dan ada firman Allah yang tertulis seperti Sepuluh Perintah Allah (Kel. 31:18). Di Perjanjian Baru (PB) kita mendapati bahwa Yesus memandang PL sebagai otoritatif (contohnya Mat. 4:1-11), Paulus memandang PL sebagai firman Allah (2Tim. 3:16), Petrus melihat nubuat PL adalah dari Roh Kudus (2Pet. 1:21). Penulis PB mengklaim bahwa PB juga adalah firman Allah, contohnya Petrus yang melihat tulisan Paulus sejajar dengan PL (2Pet. 3:16). ${ }^{11}$

Kedua, Alkitab yang membuktikan dirinya sendiri merujuk kepada Alkitab mengandung tanda-tanda atau bukti-bukti internal bahwa ia adalah firman Allah di dalam Alkitab itu sendiri. ${ }^{12}$ Bukti-bukti ini adalah sebagai berikut. Pertama, keindahan dan keunggulan Alkitab. Karena Alkitab berasal dari Allah yang sempurna maka Alkitab menunjukkan karakter-karakter keindahan dan kesempurnaan Allah. Itulah sebabnya firman Tuhan disebut sempurna (Mzm. 19:8), murni (Mzm. 19:9), manis (Mzm. 119: 103), ajaib (Mzm. 119:129). Kedua, kekuatan dan keefektifan Alkitab. Alkitab memiliki kuasa dan efektif terhadap pembaca dan pendengarnya. Ia memberi hikmat (Mzm. 119: 98; 2Tim. 3:16), sukacita di hati (Mzm. 119:111), menjadi terang bagi jalan kehidupan (Mzm. 119:105), memberi penghiburan (Mzm. 119: 50), menyibak dosa dan kesalahan (2Raj. 22:11-13; Kis. 2:34-38), dan membawa damai sejahtera dan berkat (Mzm. 1:1-3). Alkitab memiliki kuasa untuk mengubah, memben-

${ }^{11}$ Lau, "Knowing the Bible," 990-991; Grudem, "Scripture's Self-Attestation," 19-27, 37-51.

${ }^{12}$ Kruger, Canon Revisited, 97, Kruger menyebutkan tiga kualitas ilahi Alkitab namun para teolog Reformed pada era ortodoks Reformed (kira-kira 15201725) memiliki daftar yang berbeda-beda satu dengan yang lain di dalam hal banyaknya kualitas ilahi tersebut dan urutannya, lih. Richard A. Muller, PostReformation Reformed Dogmatic, vol. 2, Holy Scripture, ed. ke-2 (Grand Rapids: Baker, 2003), 270. tuk, mentransformasi pembaca atau pendengarnya. ${ }^{13}$ Ketiga, kesatuan dan harmoni dari Alkitab. Allah selalu konsisten dengan diri-Nya sendiri dan tidak pernah bertentangan dengan diri-Nya sendiri (Mzm. 89:35; Ams. 14:5; Tit. 1:2; Ibr. 13:8) sehingga segala tulisan yang dilhamkan Allah tidak pernah bertentangan satu dengan yang lain.

Namun apa hakikat dari kesatuan Alkitab ini? Michael Kruger memberikan tiga macam kesatuan di dalam Alkitab. ${ }^{14}$ Yang pertama adalah kesatuan doktrinal di dalam Alkitab yang terlihat di dalam pengajaranpengajarannya tentang, di antaranya, hakikat Allah, hakikat manusia, kedudukan bangsa Israel di dalam rencana keselamatan Allah, tujuan dan struktur gereja, pribadi dan karya Yesus Kristus, berita tentang penebusan dan pengampunan, pentingnya kekudusan, peran dan fungsi sakramen, dan konsep eskatologi. ${ }^{15}$ Yang kedua adalah kesatuan redemptif-historis, yakni Alkitab dari kitab Kejadian sampai Wahyu menceritakan sebuah metanarasi penebusan Allah yang mendamaikan manusia yang berdosa dengan diri-Nya melalui pribadi dan karya Yesus Kristus. ${ }^{16}$ Kesatuan ini memperlihatkan bahwa Alkitab yang terdiri dari berbagai kitab adalah berasal dari Allah. Yang ketiga adalah kesatuan struktural, yakni Alkitab baik PL dan PB, memiliki struktur kovenantal dan berfungsi sebagai dokumen kovenan antara Allah dan umat-Nya. ${ }^{17}$ Terdapat kesejajaran antara PL dan PB sebagai dokumendokumen kovenantal sehingga ada kesatuan

\footnotetext{
${ }^{13}$ Ibid. 127-133; lih. juga Paul Helm, "Faith, Evidence, and Scriptures," dalam Scripture and Truth, ed. D.A. Carson dan J.D. Woodbridge (Grand Rapids: Baker, 1992), 310.

${ }^{14}$ Ibid., 133-158.

${ }^{15}$ Ibid., 134.

${ }^{16}$ Ibid., 148; lih. juga Gordon D. Fee dan Douglas Stuart, How To Read the Bible Book by Book (Grand Rapids: Zondervan, 2002), 14-20.

${ }^{17}$ Ibid., 150; Kevin J. Vanhoozer, The Drama of Doctrine (Louisville: Westminster John Knox, 2005), 137-139.
} 
antara PL dan PB di mana PB berfungsi sebagai dokumen dari kovenan yang baru. ${ }^{18}$ Kesatuan struktural juga terlihat jika PL dan PB dipandang sebagai sebuah bentuk kanon Alkitab yang final. Di dalam bentuk final kanon Alkitab kita akan menemukan inklusio dan kiasme makro dari kitab Kejadian sampai Wahyu. Kitab Kejadian mulai dengan penciptaan langit dan bumi (Kej. 1) dan kitab Wahyu diakhiri dengan penciptaan ulang dan langit dan bumi yang baru (Why. 21:1). Kejadian dimulai dengan firdaus di Taman Eden (Kej. 2:8-17) dan kitab Wahyu diakhiri dengan firdaus di surga (Why. 21:4). Kejadian mulai dengan Allah diam bersama umat-Nya (Kej. 2:8; 3:8) dan Wahyu diakhiri dengan Allah akhirnya diam bersama-sama dengan umat-Nya kembali (Why. 21:3). ${ }^{19}$ Selain inklusio, Alkitab kita juga memperlihatkan kiasme yang berpusat dengan Yerusalem. Narasi PL bergerak dari penciptaan alam semesta ke satu kota yakni Yerusalem dan satu pribadi yakni Mesias. PB bergerak dari Mesias yang kembali ke Yerusalem ke arah Samaria, Yudea, Asia Kecil dan akhirnya berakhir dengan fokus kepada segala ciptaan (Kis. 1:8, 8:4-5; Kol. 1:23; Why. 7:9). ${ }^{20}$ Keterkaitan struktural tersebut memperlihatkan adanya kesatuan antara PL dan PB yang menunjukkan bahwa kanon Alkitab bukan sekedar buatan manusia tetapi adalah karya Allah sendiri.

Ketiga, Alkitab membuktikan dirinya sendiri berarti Alkitab itu sendiri menyediakan arahan dan petunjuk mengenai bagaimana Alkitab itu dibuktikan. Alkitab itu sendiri menetapkan cara bagaimana Alkitab diabsahkan dan dibuktikan kebenarannya

${ }^{18}$ Meredith G. Kline, The Structure of Biblical $\mathrm{Au}$ thority, ed. ke-2 (Eugene: Wipf \& Stock, 1997), 45-75, 172-203.

${ }^{19}$ Kruger, Canon Revisited, 156. Untuk penjelasan singkat tentang inklusio dan kiasme lih. Grant T. Osborne, Hermeneutical Spiral, edisi revisi (Downers Grove: InterVarsity, 2006), 54-55; Tremper Longman III, Bagaimana Menganalisa Kitab Mazmur, terj. Cornelius Kuswanto (Malang: SAAT, 1992), 113-114, 121.

${ }^{20}$ Ibid., 156. sebagai firman Tuhan. ${ }^{21}$ Dengan demikian, berkenaan dengan Alkitab yang membuktikan dirinya sendiri, seseorang tidak dapat membuktikan dan mengabsahkan Alkitab sebagai firman Tuhan tanpa melibatkan Alkitab itu sendiri. Pengertian ketiga ini muncul sebagai akibat dari pengakuan kita bahwa Alkitab sebagai firman Tuhan adalah otoritas tertinggi untuk menentukan kebenaran.

Jadi Alkitab membuktikan dirinya sendiri dalam tiga cara yakni klaim Alkitab terhadap diri sendiri, Alkitab yang menunjukkan tanda-tanda bahwa ia berasal dari Allah, dan Alkitab mengatur bagaimana Alkitab diperlihatkan sebagai firman Allah. Namun jika Alkitab membuktikan dirinya sendiri sebagai firman Tuhan mengapa ada orang-orang yang tidak menerima Alkitab sebagai firman Tuhan? Mengapa ada orang-orang yang tidak menerima klaim Alkitab dan melihat bukti-bukti internal di dalam Alkitab itu sendiri? Di sini kita bertemu dengan konsep pengaruh dosa terhadap daya-daya kognitif kita (noetic effects of $\sin$ ).

\section{PENGARUH DOSA TERHADAP DAYA- DAYA KOGNITIF MANUSIA DAN PEMBACAAN ALKITAB}

\section{Natur Dari Dosa}

Wayne Grudem mendefinisikan dosa sebagai "any failure to conform to the moral law of God in act, attitude, or nature." 22 Dosa pada dasarnya adalah pemberontakan religius kepada Allah yakni sebuah pelanggaran terhadap hukum Allah yang Ia nyatakan di dalam firman-Nya. Jika perintah Allah yang terutama dan pertama adalah mengasihi Tuhan Allah maka dosa adalah keterpisahan dari, kebencian, atau perlawanan kepada Allah yang terwujudnyatakan di dalam pikiran,

\footnotetext{
${ }^{21}$ Ibid., 91.

${ }^{22}$ Wayne Grudem, Systematic Theology: An Introduction to Biblcal Doctrine (Grand Rapids: Zondervan, 1994), 490.
} 
kata-kata, dan tindakan-tindakan. ${ }^{23}$ Dosa memiliki sumbernya di dalam hati manusia sebagai inti terdalam dari seorang manusia dan sebagai titik konsentrasi dari semua fungsi-fungsi manusia. ${ }^{24}$ Dari hati dosa juga mempengaruhi dan menyebar kepada daya intelek, kehendak, dan afeksi-afeksi manusia bahkan sampai kepada tubuhnya. Dosa dari dalam hati mempengaruhi seluruh aspek dari manusia dan tidak ada bagian di dalam diri manusia yang tidak tercemar oleh dosa.

Dosa memang tidak mengubah substansi manusia atau menambahkan suatu substansi baru kepada manusia. Sebelum dan setelah kejatuhan manusia dalam dosa, manusia pada dasarnya adalah ciptaan yang sama dengan substansi yang sama, kapasitaskapasitas yang sama, dan kekuatan yang sama. Yang berubah adalah arah atau tujuan yang ke arahnya kapasitas-kapasitas manusia itu berfungsi. Manusia yang berdosa memakai seluruh keberadaan dirinya termasuk hakikatnya, kemampuan-kemampuan mental dia, dan seluruh kekuatan dia untuk melayani dosanya yaitu melawan dan memberontak kepada Allah. Herman Bavinck menjelaskannya dengan baik:

While they remained essentially and substantially the same, that is, human, and kept all their human components, capacities, and powers, the form, the character and nature, the set and direction of all these capacities and powers were so changed that now, instead of fulfilling the will of God, they fulfill the law of the flesh." ${ }^{25}$

${ }^{23}$ Louis Berkhof, Systematic Theology (Grand Rapids: Eerdmans, 1984), 232; Thio Christian Sulistio, "Christian Exclusivism as Warranted Christian Doctrine" (disertasi D.Th., Trinity Theological College, 2013), 198.

${ }^{24}$ Anthony Hoekema, Created in God's Image (Grand Rapids: Eerdmans, 1994), 172; Berkhof, Systematic Theology, 233.

${ }^{25}$ Herman Bavinck, Reformed Dogmatics: Sin and Salvation in Christ, terj. John Vriend (Grand Rapids: Baker, 2006), 3:140.

\section{Dampak Noetika Dosa terhadap Pengetahuan Manusia akan Allah dan Alkitab}

Dosa mempengaruhi daya-daya kogntif kita yakni mekanisme mental di dalam diri kita yang menghasilkan kepercayaan (belief) sehingga daya-daya kognitif tersebut tidak bekerja sebagaimana mestinya. ${ }^{26}$ Pengaruh dosa terhadap daya kognitif kita juga berdampak terhadap pengetahuan kita akan Allah. Jika daya-daya kognitif kita bekerja sebagaimana mestinya yakni sesuai dengan rancangannya maka mereka akan menghasilkan pengetahuan dan kepercayaan akan keberadaan Allah dan akan membawa manusia ke dalam penyembahan kepada Allah yang benar. ${ }^{27}$ Tetapi karena pengaruh dosa terhadap daya kognitif kita maka mereka menjadi tidak berfungsi sebagaimana mestinya dan tidak mampu mempersepsi Allah itu sendiri atau mempersepsi Allah melalui karya ciptaan-Nya sebagaimana mestinya. Manusia berdosa malah menindas pengetahuan tentang Allah yang mereka terima dari wahyu umum dan mengubahnya menjadi konsepkonsep yang tidak benar tentang Allah. Oliphint menjelaskan: "instead of acknowledging God's revelation (and repenting on the basis of it), we twist and pervert it, turning it into (exchange it for) something false, something of our own imaginings, something that we ourselves have invented." ${ }^{28}$ Kita membentuk

\footnotetext{
${ }^{26}$ Rik Peels, "Sin and Human Cognition of God" Scottish Journal of Theology 64, no. 4 (2011): 395-396; Sulistio, "Christian Exclusivism," 202.

${ }^{27}$ Alvin Plantinga menyebut daya kognitif kita yang menghasilkan pengetahuan akan Allah sebagai sensus divinitatis. Sensus divinitatis akan menghasilkan berbagai kepercayaan kepada Allah sebagai respons kepada berbagai macam kondisi atau stimulus yang memicu bekerjanya sensus divinitatis ini yang akan menghasilkan pengetahuan akan Allah. Sensus divinitatis ini bekerja bukan berdasarkan penalaran tetapi persepsi langsung terhadap alam semesta (bdk. Plantinga, Warranted Christian Belief, 173).

${ }^{28} \mathrm{~K}$. Scott Oliphint, "The Irrationality of Unbelief: An Exegetical Study," dalam Revelation and Reason: New Essays in Reformed Apologetics, ed. K. Scott Oliphint dan Lane Tipton (Phillipsburg: P\&R, 2007), 69.
} 
konsep-konsep yang tidak benar akan Allah dan mendandaninya menjadi gambaran $\mathrm{Al}$ lah palsu yakni berhala. Manusia kehilangan pengetahuan yang benar akan Allah, gagal untuk mendapatkan pengetahuan akan Allah melalui perjumpaannya dengan-Nya dan menghasilkan pengetahuan yang salah tentang Allah yang kemudian menjadi pengetahuan akan berhala (yang berfungsi sebagai pengganti Allah yang sejati). ${ }^{29}$

Bagaimana pengaruh dosa terhadap pengetahuan manusia terhadap Alkitab sebagai firman Allah? Calvin menjelaskan bahwa pikiran manusia berdosa seperti manusia yang buta yang tidak mampu melihat matahari yang bersinar. Meskipun Alkitab kebenarannya jelas dan bersinar seperti matahari namun kebenaranya tidak dapat menembus pikiran manusia yang berdosa. ${ }^{30}$ Kebutaan rohani di dalam diri manusia yang membuat pikiran manusia berdosa tidak bisa melihat tanda-tanda ilahi di dalam Alkitab dan tidak dapat menerima Alkitab sebagai berasal dari Allah. John Owen menjelaskan: "Those who are under the power of their natural darkness and blindness ... cannot see or discern that divine excelency in the Scripture, without an apprehension whereof no man can believe it aright to be the word of God." 31 Pikiran manusia berdosa tidak dapat membedakan antara tulisan manusia biasa dengan firman Allah dan menganggap bahwa firman Allah hanya buku biasa dan isi Alkitab hanya opini

\footnotetext{
${ }^{29}$ Peels, "Sin and Human Cognition," 406.

${ }^{30}$ Calvin, Institutes of the Christian Religion, 3.2.34; Sulistio, "Kesaksian Internal Roh," 248. John S. Feinberg, Light in A Dark Place: The Doctrine of Scripture (Wheaton: Crossway, 2018), 574 menyebut kebutaan spiritual ini sebagai kebutaaan kedagingan (carnal blindness) di mana orang-orang yang mengalami kebutaan ini tidak dapat memahami kebenarankebenaran rohani dari wahyu khusus Allah.

${ }^{31}$ John Owen, The Works of John Owen, vol. 4, The Work of The Spirit, ed. William H. Goold (Carlislie: Banner of Truth, 2013), 57; David J. McKinley, "John Owen's View of Illumination: An Alternative to the Fuller-Erickson Dialogue," Bibliotheca Sacra 154, no. 613 (1997): 97.
}

dari orang-orang Yahudi dan Kristen. ${ }^{32}$ Manusia berdosa bukan hanya salah memahami Alkitab sebagai buku manusia biasa tetapi juga membenci dan menyangkal Alkitab. Untuk mengatasi problem ini maka diperlukan karya Roh Kudus yang mencerahkan pikiran manusia untuk dapat menerima kebenaran dan otoritas Alkitab yang disebut sebagai kesaksian internal Roh Kudus (internal testimony of the Holy Spirit).

\section{KESAKSIAN INTERNAL ROH KUDUS}

Kesaksian internal Roh Kudus merupakan tindakan Roh Kudus yang menolong manusia berdosa untuk dapat menerima kebenaran bahwa Alkitab adalah firman Tuhan dan berasal dari Allah dan dengan demikian menerima otoritas firman Allah tersebut. Namun bagaimana mekanisme karya Allah Roh Kudus ini bekerja di dalam daya-daya kognitif manusia berdosa? Menurut hemat penulis ada dua cara yang mungkin di mana Allah Roh Kudus bekerja menghasilkan kepercayaan (belief) bahkan pengetahuan (yakni kepercayaan yang benar dan terjamin) di dalam diri manusia terhadap Alkitab sebagai firman Allah. ${ }^{33}$ Cara pertama adalah melalui penerimaan manusia terhadap kesaksian ilahi melalui Alkitab dan cara kedua adalah melalui persepsi manusia terhadap fakta atau bukti internal Alkitab sebagai firman Tuhan. ${ }^{34}$

\footnotetext{
${ }^{32}$ Ramm, The Witness of the Spirit, 66.

${ }^{33}$ Sejalan dengan Alvin Plantinga, penulis menggunakan istilah jaminan (warrant) dan bukan justifikasi (justification) untuk menunjuk kepada unsur ketiga yang dibutuhkan selain kebenaran dan kepercayaan untuk menjadikan sebuah proposisi pengetahuan. Lihat penjelasan tentang perbedaan jaminan dan justifikasi di James Beilby, Epistemology as Theology: An Evaluation of Alvin Plantinga's Religious Epistemology (Aldershot: Ashgate, 2005), 82-86; Alvin Plantinga, Warrant and Proper Function (Oxford: Oxford University Press, 1993), v.

${ }^{34}$ Lihat Plantinga, Warranted Christian Belief, 251, 304-305; James Anderson, Paradox in Christian Theology: An Analysis of Its Presence, Character, and Epistemic Status (Milton Keynes: Paternoster, 2007), 186188, 202-203.
} 
Kita akan melihat cara pertama lebih dulu yakni melalui penerimaan manusia berdosa terhadap kesaksian Allah melalui Alkitab. Di dalam cara pertama ini, Alkitab dipandang memberikan kesaksian (testimony) tentang dirinya sendiri bahwa ia adalah firman Allah. Plantinga menjelaskan bahwa kesaksian Alkitab adalah unik karena Allah, yakni Allah Roh Kudus, sebagai pengarang utama Alkitab adalah penyaksi yang utama (principal testifier) dan manusia sebagai penulis teks Alkitab sebagai penyaksi yang kedua atau penyaksi yang lebih rendah (subordinate testifiers). ${ }^{35}$ Hal ini dapat terjadi karena Allah Roh Kudus melakukan supervisi atau mempengaruhi penulis-penulis Alkitab sehingga mereka, sesuai dengan kepribadian dan latar belakang mereka, menuliskan apa yang Allah Roh Kudus kehendaki. Di dalam teologi Kristen, karya Allah Roh Kudus ini disebut sebagai inspirasi Alkitab. ${ }^{36}$ Melalui karya Roh Kudus ini maka kesaksian manusia menjadi kesaksian Allah juga. ${ }^{37}$

Di dalam diri kita manusia, kita secara natural memiliki daya kognitif yang yang dirancang untuk membentuk kepercayaan berdasarkan kesaksian orang lain. Kesaksian merupakan sumber dari banyak kepercayaankepercayaan kita yang penting. Bahkan Plantinga mengatakan: "Testimony is the source of an enormously large proportion of our most important beliefs; it is testimony and learning from others that makes possible intellectual achievement and culture; testimony is the very foundation of civilization." 38 Kepercayaan yang dihasilkan melalui kesaksian ini adalah kepercayaan yang bersifat mendasar (basic belief). Ia tidak dihasilkan melalui penarikan kesimpulan induktif atau penalaran

\footnotetext{
${ }^{35}$ Ibid., 252.

${ }^{36}$ Mats Wahlberg, Revelation as Testimony: A Philosophical-Theological Study (Grand Rapids: Eerdmans, 2014), 113.

${ }^{37}$ Wahlberg membahas berbagai macam cara dimana tulisan dan tindakan penulis Alkitab menjadi tulisan dan tindakan Allah di dalam ibid., 110-114.

${ }^{38}$ Plantinga, Warrant and Proper Function, 77.
}

logis atau berdasarkan bukti dari kepercayaan lain tetapi secara langsung dari pertemuan daya kognitif kita dengan realitas (dalam hal ini kesaksian orang lain). Ia juga disebut kepercayaan mendasar karena justifikasi atau jaminan yang diterima oleh kepercayaan ini tidak berdasar kepercayaan yang lain tetapi dari persentuhan daya kognitif kita dengan realitas di luar kita. ${ }^{39}$ Jika kepercayaan ini dihasilkan oleh daya kognitif manusia yang berfungsi sebagaimana mestinya dan tidak memiliki kepercayaan lain yang bertentangan dengannya (defeater) maka kepercayaan tersebut memiliki jaminan (warrant) dan menjadi pengetahuan (knowledge).

Jika kita memahami Alkitab sebagai kesaksian dan manusia memiliki daya kognitif natural untuk membentuk kepercayaan berdasarkan kesaksian maka bagaimana karya Roh Kudus di sini? Di sini Roh Kudus bekerja memperbaiki daya kognitif kita yang berkaitan dengan penerimaan kesaksian dari Allah yang telah tidak berfungsi sebagaimana mestinya karena pengaruh dosa. Pengaruh dosa membuat daya kognitif kita yang berkaitan dengan penerimaan kesaksian Allah Roh Kudus menjadi terlalu skeptis dan dipenuhi dengan keraguan. Karena karya Roh Kudus ini maka orang menjadi terbuka terhadap kesaksian Allah Roh Kudus melalui penulis Alkitab dan menghasilkan kepercayaan terhadap Alkitab sebagai firman Allah. Roh Kudus juga mempengaruhi orang dan memperkuat kepercayaan tersebut sehingga kepercayaan tersebut dipegang dengan kuat secara psikologis (menghasilkan kepastian psikologis) dan cukup kuat untuk menjadi pengetahuan. Jika kepercayaan ini adalah hasil dari daya kognitif yang berfungsi sebagaimana mestinya (meski diperkuat oleh Roh Kudus) dan daya kognitif ini bekerja dalam lingkungan yang tepat dan bertujuan untuk menghasilkan kepercayaan yang benar

\footnotetext{
${ }^{39}$ Beilby, Epistemology as Theology, 42-43.
} 
maka kepercayaan yang dihasilkan adalah terjamin dan benar. ${ }^{40}$ Kepercayaan yang dihasilkan karena karya Roh Kudus terhadap daya kognitif manusia selalu kepercayaan yang benar. Di sini ketika seseorang membaca kesaksian penulis Alkitab, seperti misalnya 2 Timotius 3:16 atau 2 Petrus 1:20-21, maka orang tersebut, dengan bantuan Roh Kudus, akan menerima kesaksian tersebut dan menghasilkan kepercayaan di dalam dirinya bahwa Alkitab adalah firman Allah dan berasal dari Allah. Karya Roh Kudus di sini tidak menambahkan pengetahuan baru kepada seseorang atau pewahyuan yang baru.

Kepercayaan yang dihasilkan dengan mekanisme ini adalah kepercayaan yang bersifat langsung dan mendasar (basic) karena kepercayaan tersebut tidak dihasilkan dari sebuah penalaran terhadap argumen atau berdasarkan penarikan kesimpulan. Kepercayaan tersebut juga memiliki jaminan secara langsung bukan dari perpindahan jaminan dari kepercayaan lain yang sudah terjamin. ${ }^{41}$ Seorang yang menerima kesaksian internal

\footnotetext{
${ }^{40}$ Penulis menggunakan teori epistemologi Alvin Plantinga yang menyatakan bahwa suatu kepercayaan terjamin apabila kepercayaan tersebut dihasilkan oleh sebuah daya kognitif yang bekerja sebagaimana mestinya di dalam sebuah lingkungan epistemik yang pas bagi daya kognitif tersebut dan yang bertujuan menghasilkan kebenaran. Plantinga, Warranted Christian Belief, 204; Michael Bergmann, Justification Without Awareness: A Defense of Epistemic Externalism (Oxford: Oxford University Press, 2006), 132-133; Beilby, Epistemology as Theology, 86. Teori epistemologi Plantinga termasuk ke dalam golongan eksternalisme yang berpendapat bahwa faktor-faktor yang menjamin sebuah kepercayaan tidak dapat atau harus dapat diakses secara kognitif oleh subyek yang percaya. Sebagai contoh proses kausal di dalam kepercayaan seseorang tidak harus disadari oleh subyek yang mengetahui untuk pengetahuannya terjamin. J.P. Moreland dan William Lane Craig, Philosophical Foundations for a Christian Worldview, ed. ke-2 (Downers Grove: InterVarsity, 2017), 66. Di dalam teori epistemologi Plantinga, kepercayaan yang dihasilkan melalui kesaksian internal Roh Kudus memiliki jaminan, justifikasi, dan rasional.

${ }^{41}$ Plantinga, Warranted Christian Belief, 259.
}

Roh Kudus tidak perlu bernalar di dalam lingkaran setan bahwa karena Alkitab mengklaim diinspirasikan oleh Allah maka Alkitab adalah benar. Hal ini karena orang Kristen tersebut tidak membuat kesimpulan tentang inspirasi Alkitab dari pengajaran Alkitab. Kepercayaan bahwa Alkitab adalah firman Allah dibentuk dengan cara mendasar di mana pembacaan terhadap kesaksian Alkitab berfungsi sebagai pencetus dari kepercayaan tersebut dan kesaksian Alkitab menjadi dasar (ground) dari kepercayaan tersebut dan Roh Kudus menjadi penyebab efisien dari kepercayaan tersebut. ${ }^{42}$

Cara kedua adalah melalui persepsi manusia terhadap bukti internal Alkitab. Di dalam cara kedua ini, Alkitab menunjukkan kualitaskualitas bahwa ia berasal dari Allah, yaitu keindahan, kesempurnaan, kuasa, keefektifan, dan kesatuan dari Alkitab sebagaimana yang sudah dijelaskan di atas. Kita sebagai manusia memiliki daya kognitif persepsi sebagai bagian daya kognitif kita yang natural untuk menghasilkan pengetahuan. Persepsi merupakan daya kognitif yang menghasilkan pengetahuan karena interaksi langsung dengan obyek di sekeliling kita. Jika pengetahuan ini dihasilkan oleh daya kognitif yang bekerja sebagaimana mestinya dan berada dalam lingkungan yang tepat untuk daya kogntif tersebut bekerja dan daya kognitif tersebut bekerja untuk menghasilkan kebenaran maka kepercayaan tersebut terjamin. ${ }^{43}$ Di dalam kesaksian internal Roh Kudus, Roh Kudus bekerja memperbaiki daya kognitif seseorang berkaitan dengan persepsi terhadap kualitas-kualitas ilahi Alkitab sebagai tanda bahwa ia berasal dari Allah sehingga orang itu menghasilkan kepercayaan bahwa Alkitab adalah firman Allah. Roh Kudus juga bekerja memperkuat kepercayaan yang dihasilkan oleh daya kognitif tersebut sehingga dapat menjadi pengetahuan.

\footnotetext{
${ }^{42}$ Anderson, Paradox in Christian Theology, 186188, 202.

${ }^{43}$ Plantinga, Warrant and Proper Function, 89.
} 
Kepercayaan yang dihasilkan bukan hasil dari penarikan kesimpulan seperti berikut: Alkitab menunjukkan kualitas-kualitas K1, $\mathrm{K} 2$, dan K3. K1, K2, dan K3 merupakan tanda kepengarangan ilahi karena itu Alkitab memiliki pengarang ilahi oleh sebab itu adalah firman Allah. ${ }^{44}$ Kepercayaan yang dihasilkan adalah secara langsung sama seperti kepercayaan bahwa ada komputer di depan mata kita dihasilkan secara langsung oleh persepsi mata kita. Plantinga menjelaskan demikian:

A perception of the glory and beauty of the teaching in question would be an occasion of the formation of the belief that the teaching is, indeed, from God (and is true), but the transition from the one to the other would not be by way of an inference. The belief in question would be held in the basic way, although occasioned by the perception of something else (the beauty and glory of the teaching in questions).$^{45}$

Di dalam pemahaman ini, kualitas-kualitas Alkitab yang dipersepsi oleh seseorang menjadi dasar kepercayaan orang tersebut sedangkan Roh Kudus menjadi penyebab efisien dari kepercayaan tersebut. Kepercayaan yang dihasilkan bukan hanya terjamin tetapi juga benar. Mengomentari konsep Calvin tentang kesaksian internal Roh Kudus, Paul Helm berkata:

Calvin thinks that the immediate selfevidencing character of the cognitive content of Scripture is truth-guaranteeing since it is immediate evidence from God who is himself infallible. Such a one-step approach is superior to multi-step approaches precisely because it does not depend upon

\footnotetext{
${ }^{44}$ Anderson, Paradox in Christian Theology, 203,

${ }^{45}$ Plantinga, Warranted Christian Belief, 305. Plantinga di sini memang berbicara tentang keindahan dan kemuliaan pengajaran Injil tetapi konsep persepsi terhadap keindahan Injil dapat dikenakan juga kepada keindahan dan kemuliaan Alkitab sebagai tanda bahwa Alkitab berasal dari Allah.
}

fallible intermediaries nor the accumulation of probabilities. ${ }^{46}$

Kualitas-kualitas Alkitab yang bersifat terbukti dengan sendirinya (seperti warna merah kepada mata dan rasa manis terhadap lidah) adalah bukti langsung dari Allah maka kepercayaan yang dianut oleh seseorang berkaitan dengan kualitas-kualitas Alkitab tersebut adalah benar. Jaminan kebenaran kepercayaan itu juga diperkuat dengan karya Roh Kudus yang akan membimbing orang ke dalam kebenaran.

Dari pemaparan ini kita dapat menyimpulkan beberapa hal. Pertama, seseorang yang percaya bahwa Alkitab adalah firman Allah adalah dengan cara langsung yakni melalui alat kognitif kesaksian dan persepsi tanpa melibatkan proses penarikan kesimpulan dan penalaran lewat argumen. Kesaksian internal ini bersifat satu langkah sama seperti persepsi kita terhadap benda di depan kita. Kedua, jaminan dari kepercayaan ini juga bukan dipindahkan dari kepercayaan lain yang sudah terjamin tetapi ia terjamin secara langsung karena persentuhannya dengan realitas. Dengan demikian kepercayaan bahwa Alkitab adalah firman Allah adalah kepercayaan mendasar baik secara psikologis maupun secara epistemologis. Ketiga, Allah Roh Kudus bukan menjadi dasar kepercayaan tersebut tetapi hanya menjadi penyebab efisien dari kepercayaan tersebut. Kepercayaan bahwa Alkitab adalah firman Allah memiliki dasar di dalam Alkitab itu sendiri berdasarkan kesaksian Alkitab maupun kualitas-kualitas yang ditunjukkan oleh Alkitab. Keempat, meskipun kepercayaan hasil dari kesaksian internal Roh Kudus ini memiliki kepastian psikologis yang cukup tinggi namun kepercayaan ini dapat dikalahkan atau dibuat kurang kuat kepastiannya oleh kepercayaan lain yang bertentangan dengan kepercayaan pertama

\footnotetext{
${ }^{46}$ Paul Helm, John Calvin's Idea (Oxford: Oxford University Press, 2006), 270.
} 
tersebut. Seseorang dapat menjadi tidak percaya lagi bahwa Alkitab adalah firman Tuhan atau tingkat keyakinannya menurun sebagai akibat dari kehadiran kepercayaan lain yang bertentangan di dalam diri seseorang.

\section{MENJAWAB PROBLEM SIRKULARITAS TERHADAP KESAKSIAN INTERNAL ROH KUDUS}

Dengan konsep kesaksian internal Roh Kudus seperti di atas maka kita akan mencoba menjawab problem-problem yang diajukan terhadap konsep ini.

\section{Problem Sirkularitas}

Untuk menjawab problems sirkularitas, perbedaan tentang level pengetahuan yang dikembangkan oleh William Alston dapat menolong kita. ${ }^{47}$ Pengetahuan pada level pertama bersifat sederhana bahwa seseorang tahu sesuatu. Pada level kedua pengetahuan lebih bersifat reflektif tentang pengetahuan seseorang di level pertama: seseorang tahu bahwa ia tahu sesuatu. Jika ini diterapkan kepada pengetahuan kita tentang Alkitab adalah firman Allah maka pada level pertama kita tahu bahwa Alkitab adalah firman Allah melalui karya Roh Kudus yang memperbaiki daya kognitif kita sehingga kita dapat percaya kesaksian Alkitab dan melihat kualitas-kualitas Alkitab sebagai firman Allah. Pengetahuan ini kita peroleh secara langsung tanpa penarikan kesimpulan dan memiliki jaminan atau justifkasi secara langsung. Pengetahuan ini bersifat kepercayaan mendasar. Di dalam level pertama ini orang

\footnotetext{
${ }^{47}$ William Alston, Epistemic Justification: Essays in the Theory of Knowledge (Ithaca: Cornel University Press, 1989), 20, 37-38; lihat juga Michael Sudduth, "Alstonian Foundationalism and Higher-Level Theistic Evidentialism" International Journal for Philosophy of Religion, 37, no. 1 (Februari 1995): 31; C. Stephen Evans, The Historical Christ and the Jesus of Faith: The Incarnational Narrative as History (New York: Oxford University Press, 1996), 221; Kruger, Canon Revisited, 21, catatan kaki 28.
}

dapat memiliki pengetahuan tentang Alkitab tanpa mengetahui bahwa pengetahuan dia terjamin atau tanpa dapat memberikan jaminan kepada orang lain. Seseorang juga tidak perlu tahu tentang doktrin kesaksian internal Roh Kudus pada level ini agar pengetahuannya benar dan terjamin. Pengetahuan tentang kesaksian internal Roh Kudus dapat terjadi belakangan setelah dia belajar lebih banyak tentang iman dan doktrindoktrin Kristen. Pengetahuan seseorang tentang Alkitab sebagai firman Allah di dalam level pertama ini tidak memiliki problem sirkularitas. Di level ini dasar pengetahuan seseorang bahwa Alkitab adalah firman Allah adalah firman Allah itu sendiri. Roh Kudus hanya berperan sebagai penyebab efisien terhadap kepercayaan tersebut dan bukan sebagai dasar pengetahuan. Sebagai contoh, pada waktu orang yang menderita rabun jauh menggunakan kaca mata minus dan melihat Gunung Kawi dengan jelas maka ia percaya bahwa di depannya ada Gunung Kawi. Dasar kepercayaannya adalah keberadaan Gunung Kawi itu sendiri dan bukan kaca mata tersebut. Kaca mata tersebut hanya menolongnya untuk membentuk kepercayaan yang benar dan terjamin. Demikian pula dengan kepercayaan yang dihasilkan melalui mekanisme kesaksian internal Roh Kudus. Dasar kepercayaan kita atau penyebab obyektif ada dalam Alkitab itu sendiri berupa kesaksian Alkitab dan kualitas Alkitab. ${ }^{48}$ Sedangkan Roh Kudus adalah penyebab efisien atau kekuatan yang memampukan kita untuk percaya. Karena itu Herman Bavinck mengatakan bahwa tuduhan sirkularitas terhadap kesaksian internal Roh Kudus telah dipatahkan. Ia menjelaskan mengapa: "For, strictly speaking, the testimony of the Holy Spirit is not the final ground but the means of faith. The

\footnotetext{
${ }^{48}$ K. Scott Oliphint, "Response to Critics," dalam Debating Christian Religious Epistemology: An Introduction to Five Views of the Knowledge of God, ed. John M. Depoe dan Tyler D. McNabb (London: Bloomsbury Academic, 2020), 186-187.
} 
ground of faith is, and can only be, Scripture, or rather, the authority of God, which comes upon believer materially in the content as well as formally in the witness of Scripture." ${ }^{49}$ Prosesnya di sini bersifat langsung dan hanya satu langkah dari Alkitab kepada kepercayaan di dalam diri orang percaya dan orang tersebut tidak perlu tahu tentang kesaksian internal Roh Kudus agar kepercayaannya benar dan terjamin. Jadi tidak ada penalaran sirkular di sini. ${ }^{50}$

Pengetahuan pada level kedua lebih bersifat reflektif serta dapat memikirkan dan mempertanyakan pengetahuan pada level pertama tentang sesuatu yang muncul baik dari diri sendiri maupun dari orang lain. Pada level kedua ini pertanyaan dapat diajukan mengenai rasionalitas, jaminan, dan kebenaran dari pengetahuan pada level pertama. ${ }^{51}$ Berkaitan dengan pengetahuan kita tentang kesaksian internal Roh Kudus maka pertanyaan-pertanyaan seperti ini dapat muncul: Bagaimana kita tahu bahwa kesaksian internal Roh Kudus ini benar? Bagaimana kita bisa percaya Alkitab firman Allah karena karya Roh Kudus ini? Apakah pengetahuan yang dibantu Roh Kudus ini benar? Pertanyaan ini dapat merupakan pertanyaan metafisika mengenai kebenaran kepercayaan kita di level pertama atau pertanyaan epistemologis yakni rasionalitas, justifikasi, atau jaminan dari kepercayaan di level pertama. Di dalam upaya menjawab pertanyaan-pertanyaan seperti di atas maka tidak terhindarkan lagi kita akan menemukan

\footnotetext{
${ }^{49}$ Bavinck, Reformed Dogmatics, 1:597. Menurut van den Belt, Bavinck pada edisi pertama Reformed Dogmatics mengakui adanya penalaran sirkular pada doktrin kesaksian internal Roh Kudus ini. Namun pada edisi kedua ini menyangkalnya (Henk van den Belt, The Authority of Scripture, 286). Perubahan ini terjadi karena pada edisi kedua Bavinck berpikir mengenai pengetahuan tentang Alkitab di level pertama sedangkan di edisi pertama dia melihat sirkularitas epistemik pada waktu membangun doktrin tentang kesaksian internal Roh Kudus.

${ }^{50}$ Helm, John Calvin's Idea, 247.

${ }^{51}$ Sudduth, "Alstonian Foundationalism," 31.
}

sirkularitas. Sirkularitas ini tidak terhindarkan karena pada waktu kita hendak menjawab pertanyaan-pertanyaan tersebut maka kita akan menggunakan Alkitab untuk menjawabnya. Sirkularitas ini terjadi karena fungsi Alkitab (sebagai firman Allah) adalah sebagai sumber epistemologis yang fondasional dan otoritatif (principium cognoscendi) tentang Allah, manusia, dan dunia ini (semua pengetahuan religius kita). Pada waktu kita menjawab pertanyaan berkaitan dengan sumber pengetahuan dan otoritas final ini maka kita akan berargumen secara sirkular. Alston menjelaskan:

[I]t is a theological question whether the Bible or the Church is a trustworthy source of belief, and whether practices of forming beliefs on their basis are reliable. If we want to know whether, as the Christian tradition would have it, God guarantees the Bible and the Church as a source for fundamental religious beliefs, what recourse is there except to what we know about God, His nature, purposes, plans, and actions? And where do we go for this knowledge? In the absence of any promising suggestions to the contrary, we have to go to the very sources of belief credentials of which are under scrutiny. ${ }^{52}$

Di titik ini penting untuk kita mengenali sirkularitas ini dan apakah sirkularitas ini buruk? Penalaran sirkular berkaitan dengan otoritas tertinggi di dalam epistemologi ini disebut sebagai sirkularitas epistemik (epistemic circularity) yang berbeda dengan sirkularitas logis (logical circularity). ${ }^{53}$ Sirkularitas

\footnotetext{
${ }^{52}$ Dikutip dari Evans, The Historical Christ, 281.

${ }^{53}$ Bergmann, Justification Without Awareness, 180 181. Joseph E. Torres menyebut sirkularitas epistemik sebagai sirkularitas yang baik atau koherensi yang sirkular sedangkan sirkularitas logis sebagai sirkularitas yang yang tak berujung pangkal, sebuah kesalahan penalaran, lih. Joseph E. Torres, “Appendix D” dalam John M. Frame, Apologetics: A Justification of Christian Belief, ed. Joseph E. Torres (Phillipsburg: P\&R, 2015), 255-256.
} 
epistemik muncul "in connection with beliefs about the trustworthiness or reliability of one's own belief sources-beliefs such as 'my belief source $X$ is trustworthy' or 'that belief of mine wasn't formed in that unreliable way'." 54 Sirkularitas epistemik ini dapat mempengaruhi kepercayaan kita maupun argumen yang dibangun. Sirkularitas ini muncul berkaitan dengan kepercayaan kita mengenai layak dipercayainya atau keterandalan sumber pengetahuan kita. Sirkularitas epistemik ini tidak terhindarkan bukan hanya berkaitan dengan pengetahuan religius tetapi juga dengan pengetahuan-pengetahuan kita yang lainnya. Ambil contoh sumber pengetahuan kita dari pancaindra. Kepercayaan kita bahwa pancaindra kita dapat diandalkan sebagai sumber pengetahuan adalah kepercayaan yang bersifat sirkular karena kepercayaan tersebut muncul tidak lepas dari kepercayaan bahwa pancaindra kita dapat diandalkan dan dari penggunaan pancaindra itu sendiri. ${ }^{55}$ Sirkularitas ini terjadi terhadap pengetahuan religius karena kondisi kita sebagai manusia bukan karena masalah pengetahuan religiusnya. Sirkularitas epistemik ini juga terjadi karena seseorang berupaya mempertahankan konsistensi dari sumber epistemologis yang tertinggi dan otoritatif di dalam kita membuat presentasi dan pengujian bukti sampai kepada konklusi yang hendak dibangun. Sirkularitas epistemik ini dapat kita terima.

Sirkularitas ini berbeda dengan argumen logis sirkular yaitu: sebuah argumen yang memasukkan kesimpulannya ke dalam salah satu premis esensialnya. Bergmann menjelaskan: "An argument is logically circular ... only if it includes its conclusion-the very same claim-as one of its essential premises (i.e. as a premise without which the argument

\footnotetext{
${ }^{54}$ Ibid., 180.

${ }^{55}$ William Alston, "On Knowing that We Know: The Application to Religious Knowledge," dalam Christian Perspective on Religious Knowledge, ed. C. Stephen Evans dan Merold Westphal (Grand Rapids: Eerdmans, 1993), 25.
}

would be invalid)." ${ }^{56}$ Argumentasi logis yang sirkular tidak dapat kita terima karena ia tidak memberikan justifkasi atau jaminan kepada konklusinya sehingga konklusi hanya merupakan klaim semata tanpa dasar. Penjelasan tentang status epistemologis dari kesaksian internal Roh Kudus sebagai doktrin di level kedua tidak jatuh ke dalam argumen logis yang bersifat sirkular (logical circularity). Penjelasan tentang bagaimana kita tahu bahwa Alkitab adalah firman Allah dan apakah benar Alkitab adalah firman Allah akan dipengaruhi oleh sirkularitas epistemik. Sirkularitas ini tidak terhindarkan karena peran Alkitab sebagai sumber dan otoritas terutama pengetahuan manusia tentang Allah, manusia, dan dunia luar. Sirkularitas epistemik ini juga akibat dari kesetiaan atau konsistensi seseorang di dalam menerapkan otoritas final pengetahuannya terhadap pengetahuan-pengetahuannya yang lain. Sirkularitas ini tidak buruk. ${ }^{57}$

\section{Problem Subjektivisme}

Problem ini dikemukakan oleh Gregory Dawes, seorang ateis, yang mengatakan bahwa konsep Calvin tentang kesaksian internal Roh Kudus mengindikasikan konsep kebenaran yang subyektif di mana sebuah ide dapat diketahui benar karena perasaan yakin yang menyertai ide-ide tersebut. Dawes mengatakan: "The particular subjective theory of truth implicit in Calvin's view suggests that ideas can be known to be true by virtue of the sense of certainty that accompanies them." 58 Namun problem ini hanya muncul ketika kesaksian internal Roh Kudus yang menghasilkan kepercayaan yang kuat di dalam diri seseorang diceraikan dari dasar kepercayaan itu yakni Alkitab. Dalam skenario ini, keyakinan yang kuat hanya muncul karena Roh Kudus tanpa ada dasar di luar manusia

\footnotetext{
${ }^{56}$ Bergmann, Justification Without Awareness, 181. Penekanan oleh penulis buku. Lih. juga Torres, “Appendix D," 254-255.

${ }^{57}$ Torres, “Appendix D,” 256.

${ }^{58}$ Dawes, "Religious Studies, Faith," 10.
} 
yang mendasarinya. Pandangan ini tentu saja mengarah kepada subyektivisme. Tetapi ini bukan pandangan Calvin dan teologi $R e$ formed. Dasar dari kepercayaan seseorang adalah Alkitab yang mengabsahkan dirinya sendiri dan Roh Kudus berkarya memampukan kita untuk melihat kebenaran tersebut. Sama seperti orang berkacamata minus tapi yakin akan keberadaan Gunung Kawi di depannya adalah karena keberadaan Gunung itu sendiri. R. C Sproul menolak tuduhan ini dengan mengatakan:

The internal testimony of the Holy Spirit is not a flight into mysticism or an escape into subjectivism, where personal feelings are elevated to the status of absolute authority. ... The testimony of the Holy Spirit is to the Word of God. It comes to us with the Word and through the Word. It does not come apart from or without the Word. ${ }^{59}$

Namun mengapa Dawes sampai pada kesimpulan ini? Bagi Dawes, doktrin kesaksian internal Roh Kudus adalah doktrin yang berasal dari Alkitab. Alkitab sendiri tidak memiliki bukti yang terbuka untuk semua bahwa Alkitab adalah firman Allah. Jika status Alkitab sebagai firman Allah dipertanyakan maka doktrin kesaksian internal Roh Kudus tidak memiliki dasar. Ketiadaan dasar bagi pengalaman orang percaya menyebabkan pengakuan orang percaya bahwa mereka memiliki keyakinan terhadap Alkitab karena kesaksian internal Roh Kudus menjadi tidak memiliki dasar dan bukti sehingga hanya menjadi pengakuan yang berdasarkan pengalaman yang subyektif. Dawes menjelaskan:

I have suggested that it represents a firm sense of certainty (or assurance) born of the believer's encounter with the biblical message. But once we refuse to concede

${ }^{59}$ R.C. Sroul, Essential Truths of the Christian Faith (Carol Stream: Tyndale House, 1992), 118. Penekanan oleh penulis buku.
Calvin's causal claim, what evidential force should we attribute to this confidence? Even if one finds oneself among those fortunate people who enjoy this assurance, should one regard it as a reliable indication of truth? ${ }^{60}$

Tidak ada bukti bahwa pengalaman orang percaya adalah karena Roh Kudus dan sebab itu pengalaman ini subyektif dan jatuh ke dalam subyektivisme. Namun problem ini berakar dari kesalahmengertian Dawes terhadap fungsi doktrin kesaksian internal Roh Kudus sebagai penjelasan kepada sesama orang Kristen mengenai bagaimana orang Kristen dapat menerima otoritas Alkitab sebagai firman Allah. Penjelasan ini ada pada level kedua setelah orang menerima otoritas Alkitab. Doktrin ini bukan berfungsi sebagai argumen untuk menerima Alkitab adalah firman Allah yang tentu saja adalah argumen logis yang sirkular, sebuah kesalahan penalaran (logical fallacy). Memang ada sirkularitas tetapi ini adalah sirkularitas epistemik. Dengan demikian, penting bagi orang skeptis untuk dapat menerima Alkitab sebagai firman Allah lebih dulu di level pertama. Lagi pula, sebagaimana telah dijelaskan di atas, orang dapat menerima Alkitab sebagai firman Allah sebagai kepercayaan mendasar dan tidak harus memiliki bukti atau argumen untuk dapat menerimanya secara terjamin sebagimana tuntutan Dawes.

\section{Sirkularitas dan Apologetika}

Jika pengetahuan kita tentang Alkitab pada level pertama tidak perlu bukti untuk dapat terjamin dan pengetahuan tersebut adalah hasil karya Roh Kudus maka bagaimana orang Kristen dapat membela kebenaran dan rasionalitas pengetahuan tersebut kepada orang-orang yang tidak mengalami karya Roh Kudus tersebut? ${ }^{61}$ Apalagi jika

${ }^{60}$ Ibid.

${ }^{61}$ Michael Sudduth, "Bi-Level Evidentialism and Reformed Apologetics" Faith and Philosophy 11, no. 3 (1994): 387. 
kita mengakui sirkularitas epistemik maka semua argumen kita dipengaruhi oleh sirkularitas ini. Argumen seperti ini: "Alkitab adalah firman Tuhan karena Alkitab mengatakannya" jelas tidak memiliki daya persuasi yang kuat bagi orang-orang nonkristen. Kerumitan problem ini ditambah lagi dengan fakta bahwa orang yang memiliki iman kepercayaan yang lain seperti Mormon, Islam, dan Buddha juga memiliki klaim yang sama seperti Kristen, yaitu bahwa Kitab Suci mereka mengklaim diri sebagai firman Allah dan mereka juga mengalami pengalaman yang serupa dengan kesaksian internal Roh Kudus. ${ }^{62}$ Problem ini dapat diringkas dengan pertanyaan: "Apakah doktrin kesaksian internal Roh Kudus mengizinkan penggunaan argumen dan bukti untuk membenarkan kepercayaan kita terhadap Alkitab?" Jika boleh, apakah bukti dan argumen ini dapat diakses oleh orang nonkristen?

Untuk menjawab problem tersebut, sekali lagi perbedaan level pengetahuan menolong kita. Pengetahuan pada level pertama $\left(\mathrm{PL}_{1}\right)$ dapat merupakan pengetahuan yang bersifat mendasar (basic belief) yang mendapatkan jaminannya secara langsung (immediate) dari persentuhan dengan realitas. Karena hal itu adalah kepercayaan mendasar maka kepercayaan ini tidak perlu bukti untuk membuatnya terjamin. Pengetahuan pada level kedua $\left(\mathrm{PL}_{2}\right)$ merupakan pengetahuan tentang $\mathrm{PL}_{1}$. Pengetahuan ini tentang rasionalitas, jaminan, reliabilitas, dasar, serta kebenaran dari $\mathrm{PL}_{1}$. Berbeda dengan $\mathrm{PL}_{1}$ yang bersifat mendasar dan mendapatkan jaminan secara langsung maka $\mathrm{PL}_{2}$ bersifat bukan kepercayaan mendasar (nonbasic belief), mendapatkan jaminan secara tidak langsung dari kepercayaan yang lain (mediate), bersifat evaluatif terhadap $\mathrm{PL}_{1}$, menggunakan penalaran untuk membentuknya, serta perlu memiliki dasar argumen yang cukup. ${ }^{63}$ Karena penge-

${ }^{62} \mathrm{Lau}$, "Knowing the Bible is the Word of God," 991-994, 1009-1010.

${ }^{63}$ Sudduth, "Bi-Level Evidentialism," 388. tahuan di level dua ini bersifat rasional dan memakai penalaran yang memadai maka pengetahuan ini terbuka untuk dipahami dan diselidiki oleh publik atau orang nonkristen. $\mathrm{PL}_{2}$ ini sendiri berdasarkan penalaran dan harus memiliki dasar yang memadai.

Jika kita menerima perbedaan pengetahuan di atas maka pengetahuan kita di level pertama tentang Alkitab memang tidak memerlukan penalaran dan bukti untuk dapat terjamin dan merupakan karya Roh Kudus di dalam hidup orang Kristen. Meski kepercayaan ini tidak perlu bukti bukan berarti argumen dan alasan-alasan yang memadai tidak boleh kita gunakan. Peran argumen dan bukti di dalam level ini hanya untuk mengkonfirmasi apa yang sudah kita dapat melalui kesaksian internal Roh Kudus. Sebagai contoh, seseorang percaya bahwa hari ini hujan di lokasi tempat tinggalnya berdasarkan penglihatannya secara langsung terhadap hujan yang terjadi di luar rumahnya. Namun orang tersebut juga dapat menerima pengetahuan ini berdasarkan penarikan kesimpulan. Orang tersebut, misalnya, berada dalam ruang tertutup namun ia mendengar suara guruh, suara rintik-rintik di atap rumah, dan ada orang yang masuk rumah dengan jas hujan serta payung yang basah. Pengetahuan hasil penalaran ini dapat mengonfirmasi apa yang telah dilihatnya. Demikian juga dengan orang Kristen yang percaya Alkitab firman Allah karena karya Roh Kudus. Ia percaya karena karya Roh Kudus tetapi argumen berfungsi mengkonfirmasi kepercayaannya. William Lane Craig menjelaskan: "A person who knows that Christianity is true on the basis of the witness of the Spirit may also have a sound apologetics which reinforces or confirms for him the Spirit's witness, but it does not serve as the basis of his belief." ${ }^{44}$ Tentu saja bukti dan argumen di level ini diwarnai dengan sirkularitas yang bersifat

\footnotetext{
${ }^{64}$ William Lane Craig, Reasonable Faith: Christian Truth and Apologetics, ed. ke-3 (Wheaton: Crossway, 2008), 48.
} 
epistemik karena ketundukan penalaran kepada Alkitab dan bukti ini ditujukan kepada orang Kristen itu sendiri atau sesama Kristen. ${ }^{65}$

Namun pengetahuan kita tentang jaminan dan kebenaran dari pengetahuan bahwa Alkitab adalah firman Allah perlu argumen atau penalaran yang memadai serta terbuka kepada orang-orang nonkristen. Di sini tugas orang Kristen adalah untuk memperlihatkan bahwa Alkitab benar firman Allah dengan menyertakan argumen yang benar dan valid bagi klaim bahwa Alkitab adalah firman Allah. Karena argumen di level ini tetap tunduk dan setia kepada otoritas Alkitab maka argumen di level ini pun tetap diwarnai oleh sirkularitas epistemik. John Frame membedakan argumen sirkular epistemik yang sempit serta argumen sirkular epistemik yang luas. ${ }^{66}$ Argumen sirkular epistemik yang sempit menggunakan buktibukti internal di dalam Alkitab secara langsung. Misalnya: Alkitab adalah firman Allah karena Alkitab mengatakannya, atau kualitaskualitas Alkitab menunjukkan bahwa Alkitab adalah firman Allah. Argumen seperti ini jelas tidak persuasif kepada orang-orang nonkristen sehingga perlu ada argumen yang lebih persuasif.

Kita dapat memakai argumen sirkularitas yang luas yang melibatkan data-data di luar Alkitab, seperti arkeologi, sejarah, sains, dan filsafat. Bukti-bukti di luar Alkitab dapat digunakan karena Allah meninggalkan jejakNya di dalam ciptaan-Nya dan sejarah umat manusia. Tentu saja bukti-bukti ini tetap dilihat di dalam terang Alkitab karena itu bukti-bukti tersebut tetap sirkular tetapi

\footnotetext{
${ }^{65}$ Craig menyebut pengetahuan di level pertama sebagai mengetahui kekristenan benar (knowing Christianity is true) dan pengetahuan di level kedua sebagai usaha menujukkan kekristenan benar (showing Christianity is true). Ibid., 43-58.

${ }^{66}$ Frame, Apologetics: A Justification of Christian Belief, 14-15; John M. Frame, The Doctrine of the Knowledge of God (Phillipsburg: P\&R, 1987), 131.
}

sirkularitas yang cukup luas. Dengan demikian, kita dapat berargumen bahwa Alkitab adalah firman Allah karena arkeologi, sejarah, sains, dan filsafat memberikan verifikasi terhadap apa yang Alkitab nyatakan dan ajarkan. ${ }^{67}$ Argumen ini dapat saja merupakan argumen deduktif, induktif, atau penarikan kesimpulan sebagai penjelasan yang terbaik dari data-data yang ada (inference to the best explanation atau abduction).$^{68}$ Argumen yang baik dan tunduk kepada otoritas Alkitab adalah argumen yang premis-premis dan logika argumen harus tidak bertentangan dengan pengajaran Alkitab khususnya tentang pengetahuan manusia. Ini bukan berarti bahwa semua premisnya harus diambil dari Alkitab. Selanjutnya, argumen tersebut harus memperhatikan kaidah-kaidah penalaran logis di mana permis-premisnya harus benar dan logika penalaranya valid. ${ }^{69}$ Namun argumen-argumen ini bukan argumen logis yang sirkular. Roh Kudus dapat memakai argumen yang sesuai dan tidak bertentangan dengan Alkitab itu untuk membawa seseorang meyakini kebenaran Alkitab sebagai firman Allah. ${ }^{70}$ Karena pekerjaan Roh Kudus bukan meyakinkan kita

\footnotetext{
${ }^{67}$ Frame, The Doctrine of the Knowledge, 131.

${ }^{68}$ Steven Cowan memaparkan berbagai macam argumen yang ada untuk membuktikan bahwa Alkitab adalah firman Allah. Tetapi menurut Cowan argumen yang paling baik adalah argumen pendekatan kristologis di mana kita menerima Alkitab adalah firman Allah karena Yesus Kristus mengajarkannya. Argumen ini tidak jatuh ke dalam argumen logis sirkular. Steven B. Cowan, "Is the Bible the Word of God?" dalam In Defense of the Bible: A Comprehensive Apologetic for the Authority of Scripture, ed. Steven B. Cowan dan Terry L. Wilder (Nashville: B\&H Academic, 2013), 429-463.

${ }^{69}$ Frame, Apologetics: A Justification of Christian Belief, 58.

${ }^{70}$ Craig, Reasonable Faith, 56. Di sini Roh Kudus memakai argumen dan penalaran yang adalah penerapan Alkitab ke dalam logika dan sejarah. Sepanjang argumen tersebut sesuai dengan Alkitab firman Allah maka Allah Roh Kudus dapat membuka persepsi dan penalaran seseorang untuk menerima kebenaran Alkitab sebagai firman Allah dengan kepastian yang tinggi sehingga menjadi iman. Seseorang menerima kebenaran Alkitab sebagai firman Allah berdasarkan penguraian Alkitab secara luas (sama seperti khotbah
} 
terhadap sesuatu yang tidak memiliki dasar rasional tetapi meyakinkan kita dengan memberikan penerangan dasar yang rasional yang membuat kita memiliki kewajiban menerima konklusinya. Roh Kudus menciptakan iman yang tidak buta.

Dari semua pemaparan di atas dapat dilihat bahwa kesaksian internal Roh Kudus bukanlah titik lemah dari teologi Protestantisme, melainkan batu penjuru dari pengakuan iman Kristen, seperti yang dikatakan Bavinck: "The testimony of the Holy Spirit is so far from being the Achilles's heel of Protestanism that it should rather be called the cornerstone of our Christian confession, the crown and seal of all Christian truth, the triumph of the Holy Spirit in the world." 71

\section{KESIMPULAN}

Dari pemaparan di atas kita dapat menyimpulkan bahwa di level pertama pengetahuan kita tentang Alkitab sebagai firman Allah sebagai hasil kerja kesaksian internal Roh Kudus tidak ada penalaran logis yang sirkular. Roh Kudus bekerja memperbaiki daya kognitif manusia terkait dengan persepsi terhadap kualitas-kualitas ilahi Alkitab serta terhadap penerimaan kesaksian Alkitab sebagai kesaksian Allah tentang Alkitab itu sendiri. Di titik ini pengetahuan manusia akan Alkitab sebagai firman Allah timbul karena interaksi langsung dengan Alkitab yang dibantu oleh Roh Kudus. Namun di level dua pengetahuan kita tentang Alkitab

atau bentuk penjabaran Alkitab yang lain) dan bukan argumen dari manusia yang mandiri semata. Dengan kata lain argumen yang dibentuk di sini bukan hasil dari otonomi manusia tetapi argumen yang dibangun berdasarkan prasuposisi kebenaran Alkitab. Mengembangkan istilah yang dipakai oleh Michael Sudduth, penulis menyebut argumen ini sebagai model dogmatic argument untuk Alkitab sebagai firman Allah. Michael Sudduth, Reformed Objection to Natural Theology (Burlington: Ashgate, 2009), 150152.

${ }^{71}$ Herman Bavinck, Reformed Dogmatics: Prolegomena, terj. John Vriend (Grand Rapids: Baker, 2009), 1:599. dan kesaksian internal Roh Kudus ada sirkularitas yang disebut penalaran sirkular epistemik. Penalaran sirkular epistemik ini tidak terhindarkan karena Alkitab berfungsi sebagai sumber kriteria pengetahuan kita yang tertinggi tentang hal-hal religius. Kita membangun doktrin tentang Alkitab dan Roh Kudus (termasuk doktrin kesaksian internal Roh Kudus) dan menjaminnya berdasarkan Alkitab. Sirkularitas ini juga terjadi karena kesetiaan terhadap peran Alkitab sebagai sumber pengetahuan yang memiliki otoritas tertinggi.

Kesaksian internal Roh Kudus juga tidak perlu jatuh ke dalam subyektivisme karena karya Roh Kudus ini tidak terpisahkan dari bukti internal Alkitab. Karya Roh Kudus ini bukan dasar dari kepercayaan kita bahwa Alkitab adalah firman Allah. Dasar dari kepercayaan kita ada pada Alkitab yang bersifat mengabsahkan dirinya sendiri. Kepercayaan kita terhadap Alkitab ini terjamin dan tidak perlu bukti karena dihasilkan oleh daya kognitif kita yang bekerja sebagaimana mestinya dan dalam lingkungan yang tepat (dengan keberadaan Alkitab dan Roh Kudus) yang bertujuan menghasilkan kebenaran. Meskipun di level pertama kita tidak memerlukan bukti agar kepercayaan kita terjamin namun di level kedua pengetahuan kita, kita dapat menggunakan bukti dan argumen untuk membenarkan pengetahuan kita. Bukti dan argumen yang sesuai dengan Alkitab akan dipakai Roh Kudus untuk membawa orang kepada kebenaran Allah.

\section{DAFTAR KEPUSTAKAAN}

Alston, William. "On Knowing that We Know: The Application to Religious Knowledge." Dalam Christian Perspective on Religious Knowledge, diedit oleh C. Stephen Evans dan Merold Westphal, 15-39. Grand Rapids: Eerdmans, 1993.

- Epistemic Justification: Essays in the Theory of Knowledge. Ithaca: Cornel University Press, 1989. 
Anderson, James. Paradox in Christian Theology: An Analysis of Its Presence, Character, and Epistemic Status. Milton Keynes: Paternoster, 2007.

Bavinck, Herman. Reformed Dogmatics. Vol. 1, Prolegomena. Diterjemahkan oleh John Vriend. Grand Rapids: Baker, 2009.

_. Reformed Dogmatics: Sin and Salvation in Christ. Jilid 3. Diterjemahkan oleh John Vriend. Grand Rapids: Baker, 2006.

Beilby, James. Epistemology as Theology: An Evaluation of Alvin Plantinga's Religious Epistemology. Aldershot: Ashgate, 2005.

Belt, Henk van den. The Authority of Scripture in Reformed Theology: Truth and Trust. Leiden: Brill, 2008.

Bergmann, Michael. Justification Without Awareness: A Defense of Epistemic Externalism. Oxford: Oxford University Press, 2006.

Berkhof, Louis. Systematic Theology. Grand Rapids: Eerdmans, 1984.

Berkouwer, G.C. Holy Scripture: Studies In Dogmatics. Diterjemahkan oleh Jack B. Rogers. Grand Rapids, Eerdmans, 1975.

Calvin, John. Institutes of the Christian Religion. Diterjemahkan oleh Ford Lewis Battles. Jilid 1. Philadelphia: Westminster Press, 1960.

Cowan, Steven B. "Is the Bible the Word of God?" Dalam In Defense of the Bible: A Comprehensive Apologetic for the Authority of Scripture, diedit oleh Steven B. Cowan dan Terry L. Wilder, 429-462. Nashville: B\&H Academic, 2013.

Craig, William Lane. Reasonable Faith: Christian Truth and Apologetics. Ed. ke-3. Wheaton: Crossway, 2008.

Dawes, Gregory W. Religion Philosophy and Knowledge. London: Palgrave Macmillan, 2016.

-. "Religious Studies, Faith, and Presumption of Naturalism," Jurnal Of Religion and Society 5 (2003): 1-19.

Evans, C. Stephen. The Historical Christ and the Jesus of Faith: The Incarnational Narrative as History. New York: Oxford University Press, 1996.
Fee, Gordon D. dan Douglas Stuart. How To Read the Bible Book by Book. Grand Rapids: Zondervan, 2002.

Feinberg, John S. Light in A Dark Place: The Doctrine of Scripture. Wheaton: Crossway, 2018.

Frame, John M. Apologetics: A Justification of Christian Belief. Diedit oleh Joseph E. Torres. Phillipsburg: P\&R, 2015.

. The Doctrine of the Knowledge of God. Phillipsburg: P\&R, 1987.

Grudem, Wayne. "Scripture's Self-Attestation and the Problem of Formulating a Doctrine of Scripture." Dalam Scripture and Truth, diedit oleh D.A. Carson dan John D. Woodbridge, 19-59. Grand Rapids: Zondervan, 1983.

- Systematic Theology: An Introduction to Biblical Doctrine. Grand Rapids: Zondervan, 1994.

Helm, Paul. "Faith, Evidence, and Scriptures." Dalam Scripture and Truth, diedit oleh D.A. Carson dan J.D. Woodbridge, 303320. Grand Rapids: Baker, 1992.

_ John Calvin's Idea. Oxford: Oxford University Press, 2006.

Hesselink, I. John. Calvin's First Catechism: A Commentary. Louisville: Westminster John Knox, 1997.

. "The Revelation of God in Creation and Scripture: Calvin's Theology and Its Early Reception.” Dalam Calvin's Theology and Its Reception, diedit oleh J. Todd Billings dan I. John Hesselink, 3-24. Louisville: Westminster John Knox, 2012. Hodge, Caspar Wistar. "The Witness of the Holy Spirit to the Bible." The Princeton Theological Review 11 (1913): 41-84, https://ia801903.us.archive.org/14/items/ princetontheolog1111arms/princeton theolog1111arms.pdf, diakses 26 Juni 2020.

Hoekema, Anthony. Created in God's Image. Grand Rapids: Eerdmans, 1994.

McKinley, David J. McKinley. "John Owen's View of Illumination: An Alternative to the Fuller-Erickson Dialogue." Bibliotheca Sacra 154, no. 613 (1997): 93-104. 
Kline, Meredith G. The Structure of Biblical Authority. Ed. ke-2. Eugene: Wipf \& Stock, 1997.

Klooster, F.H. "Internal Testimony of the Holy Spirit." Dalam Evangelical Dictionary of Theology, diedit oleh Walter A. Elwell, 610-611. Ed. ke-2. Grand Rapids: Baker Book, 2001.

Kruger, Michael J. Canon Revisited: Establishing the Origins and Authority of the New Testament Book. Wheaton: Crossway, 2012.

Lau, Te-Li. "Knowing the Bible is the Word of God Despite Competing Claims." Dalam The Enduring Authority of the Christian Scriptures, diedit oleh D.A. Carson, 9891012. Grand Rapids: Eerdmans, 2016.

Longman III, Tremper. Bagaimana Menganalisa Kitab Mazmur. Diterjemahkan oleh Cornelius Kuswanto. Malang: SAAT, 1992.

Moreland, J.P. dan William Lane Craig. Philosophical Foundations for a Christian Worldview. Edisi kedua. Downers Grove: InterVarsity, 2017.

Muller, Richard A. Post-Reformation Reformed Dogmatic. Vol. 2, Holy Scripture. Ed. ke-2. Grand Rapids: Baker, 2003.

Murray, John. "The Attestation of Scripture." Dalam The Infallible Word, diedit oleh Ned B. Stonehouse dan Paul Woolley, 942. Philadelphia: Presbyterian Guardian, 1946.

Oliphint, K. Scott. "The Irrationality of Unbelief: An Exegetical Study." Dalam Revelation and Reason: New Essays in Reformed Apologetics, diedit oleh K. Scott Oliphint dan Lane Tipton, 59-73. Phillipsburg: P\&R, 2007.

—. "Response to Critics." Dalam Debating Christian Religious Epistemology: An Introduction to Five Views of the Knowledge of God, diedit oleh John M. Depoe dan Tyler D. McNabb, 182-190. London: Bloomsbury Academic, 2020.

Osborne, Grant T. Hermeneutical Spiral. Edisi revisi. Downers Grove: InterVarsity, 2006.
Owen, John. The Work of The Spirit. Vol. 4, The Works of John Owen. Diedit oleh William H. Goold. Carlislie: Banner of Truth, 2013.

Peels, Rik. "Sin and Human Cognition of God" Scottish Journal of Theology 64, no. 4 (2011): 390-409.

Plantinga, Alvin. Warrant and Proper Function. Oxford: Oxford University Press, 1993.

- Warranted Christian Belief. Oxford: Oxford University Press, 2000.

Ramm, Bernard. The Witness of the Spirit: An Essay on the Contemporary Relevance of the Internal Witness of the Holy Spirit. Eugene: Wipf and Stock, 2011.

Sproul, R. C. Essential Truths of the Christian Faith. Carol Stream: Tyndale House, 1992.

Sudduth, Michael. "Alstonian Foundationalism and Higher-Level Theistic Evidentialism." International Journal for Philosophy of Religion, 37, no. 1 (Februari 1995): 2544.

-. "Bi-Level Evidentialism and Reformed Apologetics." Faith and Philosophy 11, no. 3 (Juli 1994): 379-396.

- Reformed Objection to Natural Theology. Burlington: Ashgate, 2009.

Sulistio, Thio Christian. "Christian Exclusivism as Warranted Christian Doctrine." Disertasi D.Th., Trinity Theological College, 2013.

_. "Kesaksian Internal Roh Kudus Menurut John Calvin.” Veritas: Jurnal Teologi dan Pelayanan 3, no. 2 (2002): 243-253, https://doi.org/10.36421/veritas.v3i2.97.

Vanhoozer, Kevin J. The Drama of Doctrine. Louisville: Westminster John Knox, 2005.

Wahlberg, Mats. Revelation as Testimony: $A$ Philosophical-Theological Study. Grand Rapids: Eerdmans, 2014.

Warfield, Benjamin B. The Inspiration and Authority of the Bible. Diedit oleh Samuel G. Craig. Philadelphia: P\&R, 1948. 
